$12-31-2020$

\title{
Village fund accountability and gendering in Masculine Hegemonic Institution: A study during COVID-19
}

\author{
Desti Fitriani \\ Faculty of Economic and Business, Universitas Indonesia, Indonesia, desti.fitriani@ui.ac.id \\ Elvia R. Shauki \\ Faculty of Economic and Business, Universitas Indonesia, Indonesia, elvia.rosantina@ui.ac.id
}

See next page for additional authors

Follow this and additional works at: https://scholarhub.ui.ac.id/ajce

Part of the Accounting Commons

\section{Recommended Citation}

Fitriani, Desti; Shauki, Elvia R.; and Pratiwi, Siti Czafrani (2020). Village fund accountability and gendering in Masculine Hegemonic Institution: A study during COVID-19. ASEAN Journal of Community Engagement, 4(2), 386-415.

Available at: https://doi.org/10.7454/ajce.v4i2.1106

Creative Commons License

(c) (i) ()

This work is licensed under a Creative Commons Attribution-Share Alike 4.0 License.

This Research Article is brought to you for free and open access by the Universitas Indonesia at ASEAN Journal of Community Engagement. It has been accepted for inclusion in ASEAN Journal of Community Engagement. 


\title{
Village fund accountability and gendering in Masculine Hegemonic Institution: A study during COVID-19
}

\author{
Desti Fitriania ${ }^{*}$, Elvia R. Shaukia, Siti Czafrani Pratiwi ${ }^{a}$ \\ ${ }^{a}$ Faculty of Economic and Business, Universitas Indonesia, Indonesia
}

Received: September 30th 2020|| Revised: November $18^{\text {th }}$ and December $14^{\text {th }}, 2020||$ Accepted: December $28^{\text {th }}, 2020$

\begin{abstract}
The study is aimed to evaluate accountability and gender roles in enhancing the accountability of village fund and other government-related assistance during COVID-19 pandemic. This study employed an integrated framework of accountability, gender socialization theory and gender subtext theory. This study applies a case study with 2 (two) types of instruments, i.e., observations and semi-structured interviews. The villages observed have provided limited information regarding the BLT DD assistance and other COVID19 related assistance. Consequently, the villagers did not have sufficient information to participate in the village decision-making process and to criticize BLT DD assistance and other COVID-19 related assistance distribution process. The villagers were not invited to any village meetings that it prevents them to provide inputs and consequences to the village government. As a result, the level of accountability regarding the information provided, a discussion held and consequences are given at a minimum level. The roles of female BPD members were insignificant due to the pervasiveness of gendering practice in village organizations. These findings contradict gender socialization theory that women with all their feminine traits are suitable and potential to perform supervisory tasks in guiding the organization. However, these findings are aligned with gender subtext theory that segregation of duties based on masculinity and femininity are apparent in the village organization.
\end{abstract}

Keywords: accountability; female BPD member; masculine hegemony; gender socialization; gender subtext.

\section{Introduction}

The economic impact of COVID-19 pandemic has begun with the weakening of Indonesia's economic growth. Economic slowdown had begun in the Quarter 1-2020 (Q1) where economic growth was only $2.97 \%$. This condition is far from the average growth in the previous year, which was around 5\%. This condition is predicted to continue at least until the Quarter 4-2020, where the economic growth may be as low as 3.4\%, or 1\% (BBC News Indonesia, 2020).

The COVID-19 pandemic has given a decisive blow to increasing poverty levels in villages. The percentage of poor people in March 2020 increased 0.56 percentage points from September 2019 to 9.78 per cent. In March 2002, the percentage of poor people in the rural area increased 0.22 points percentage from September 2019 (Badan Pusat Statistik, 2020).

In responding to the impact of COVID-19, the Government has put various initiatives to save the national economy. Village Fund Direct Cash Assistance (BLT DD) is one of those initiatives aiming for providing a social safety net to ease the burden of the communities whose economies

\footnotetext{
*Correspondence Author: desti.fitriani@ui.ac.id
} 
were affected by the pandemic. It is also expected to increase Indonesia's negative economy at 5.32 per cent occurred in the second quarter of 2020.

BLT DD is a diverted village fund to deal with the economic impact of the COVID-19 pandemic. Per month, each beneficiary family received the assistance of IDR 600,000. This type of assistance is discussed in this study. This assistance is stipulated under the Ministry of Village Regulation No. 6 of 2020. The village funds are reallocated into BLT DD, with the limits ranging from $25 \%$ to $35 \%$ out of the total village fund allocated.

After evaluating the disbursement of stage 1 BLT DD funds, the Ministry of Finance revised previous regulation by issuing Regulation Number 50 / PMK.07 / 2020 where there is no maximum limit on the allocation of Village Funds used for BLT DD. Besides, the BLT DD assistance extended for another 3 (three) months, with an additional value of Rp. 300,000 per month/household. This new regulation also provides relaxation to village government related to village fund distribution requirements.

There are obstacles in the implementation of BLT DD assistance. Corruption is a significant problem that haunts the distribution of BLT DD (Kompas.com, 2020; Siwalimanews.com, 2020). Another problem is in collecting the beneficiaries' data. The BLT DD distribution process did not involve the Village Consultative Body (BPD) and elements of community leaders. This condition was worsened by the absence of data verification and validation to ensure that no recipient receives double assistance. Not to mention the issue of transparency which is also a problem due to the closed distribution mechanism (Beritabeta.com, 2020). As a result, there is no social control that can be exercised by residents to ensure that the beneficiaries are people who truly deserve it, i.e., the accountability in the BLT DD and other government assistance.

Priority use of village fund, including the COVID-19 related assistance, should be made available to the public through any accessible media. This is mandated by the Ministry of Village Regulation No. 7 the Year 2020. Furthermore, the village budget should be submitted, reviewed, discussed, and approved by the BPD before submitting to the higher authority. In the village government governance structure, there is a supervisory body that is tasked with ensuring accountability in the implementation of village governance called the Village Consultative Body (BPD). According to Ministry of Home Affairs No. 110 the Year 2016, the function and roles of the BPD are to explore, manage and convey the aspirations of the village community, to conduct BPD and village meetings, to form the Village Head election committee, to discuss and to approve upon village regulation draft, to supervise the performance of village government, to evaluate the accountability report of village government administration, as well as to create a harmonious working relationship with the Village Government and other village 
institutions. The BPD members are representatives of the village population-based on regional representation and women's representatives who are elected based on direct elections or representative deliberations. The number of BPD members is at least 5 people, and at most 9 people. Included in this BPD membership is an element of women's representation. Women are expected to contribute to increasing accountability in village governance. Therefore, Ministry of Home Affairs regulation No. 110 the Year 2016 mandated that there should be at least 1 (one) female member in BPD.

However, the BPD has several limitations in carrying out its role. In certain villages, the BPD has a close relationship with the Village Head, therefore, their independence in supervising the village government is disrupted. Hence, the BPD tends to agree in any decisions made by the Village Government. In most cases, decisions made by the Village Heads are incontestable. Consequently, the role and function of the BPD are often neglected by the Village Head. On the other hand, in most cases, BPD members do not fully understand their roles and functions. The villagers are disadvantaged as they are not well informed with the existence, roles, and functions of BPD.

\subsection{Theoretical framework}

In the public sector context, accountability arose due to the mutual relation between an actor, the party who has been trusted to perform specified obligations, and the forum or the party who put their trust to the actor and affected by the action of the actor (Gray \& Jenkins, 1993). This relationship creates an urgency for the actor to provide an account to the forum to prevent mismanagement of public resource and to assure the improvement of fair public governance process (Aucoin \& Heinzman, 2000). Within the public sector context, accountability process is more complicated since it involves multiple forums. Public sector accountability concerns with how the information released could provide a democratic power for the forum to control the conduct of the public agent.

Accountability in the public sector is conceptualized as the process which consists of 3 (three) essential stages: actor providing information to the forum about his conduct, actor and forum discussions about the performance reported, and in the end, forum judge the performance of the actors and later the actor face consequences (Bovens, 2007; Broadbent et al., 1996; Lerner \& Tetlock, 1999; Romzek \& Dubnick, 1987; Schweiker, 1993). In the first stage of accountability, which is information providing by the actor to the forum, the data is expected to be clear, accurate, and understandable by the forum that it could encourage the forum to 
participate in the next stage of accountability, which is a discussion (Bovens, 2007; Brandsma \& Schillemans, 2013; Broadbent et al., 1996; Devas \& Grant, 2003).

The second phase of accountability, discussion, is needed as a control mechanism for the forum (Bovens, 2007; Brandsma \& Schillemans, 2013; Jantz et al., 2015). Discussion phase also creates an opportunity for the actor to learn what is expected from them (Brandsma \& Schillemans, 2013). The third stage of accountability, consequences, concerns with the reward or punishment accepted by the actors which intended as a learning mechanism (Bovens, 2007; Brandsma \& Schillemans, 2013; Jantz et al., 2015). The goal of this operating accountability mechanism is to serve as an evaluation, to see if there are any impacts have been made and whether there are lessons and feedback to improve governance. Conversely, accountability mechanisms may add to routine and administrative burdens, resulting in a lack of governance (Bovens, 2010). Bovens $(2007,2010)$ depicts the mechanism of accountability, as in Figure 1.

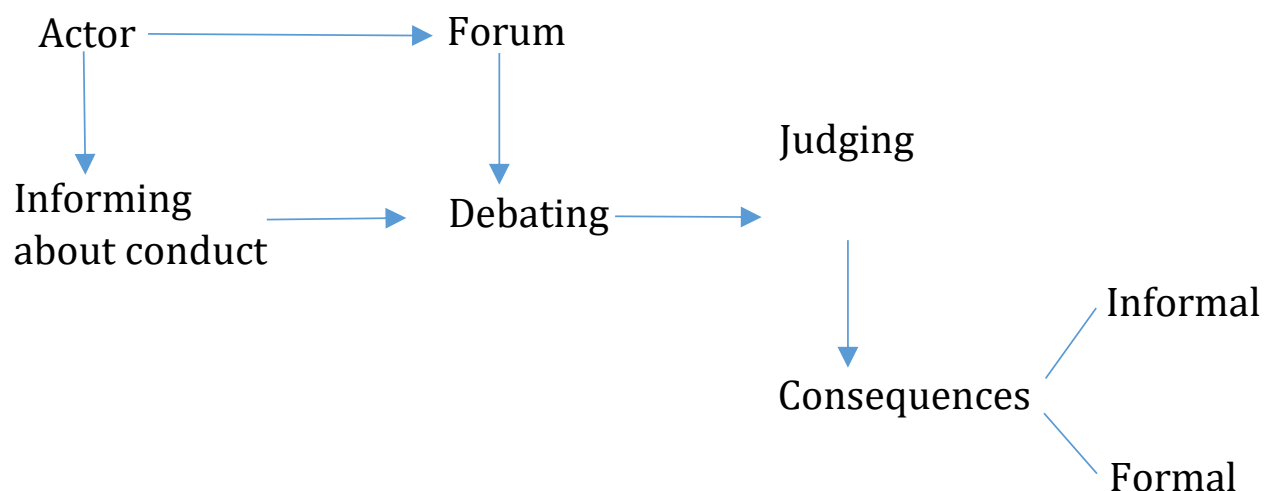

Fg. 1 Accountability Mechanism

Source: Bovens $(2007 ; 2010)$

An attempt to improve Bovens' framework of accountability was made by Brandsma \& Schillemans (2013) through the development of accountability cube. The accountability cube allows multidimensional analysis of information, discussion, and consequences stage in accountability arrangement rather than analyzing them separately as previously suggested by Bovens (2007, 2010). Accountability cube, as presented in Figure 2, allows the assessment of information, discussion, and consequences intensity by plotting each of this stage in a dimension which has a "low end and high end". Brandsma and Schillemans (2013) claimed that this accountability cube allows the assessment of accountability intensity and locating accountability deficiency. Here is still a lack of research that implements the accountability cube framework as employed by Brandsma and Schillemans (2013). Jantz and Jann (2013) implemented this framework to examine the accountability arrangement in two Scandinavian 
countries' labour market administration. This framework allows to facilitate a more robust judgement on accountability level.

The existence of accountability problems in the implementation of BLT DD has motivated this study not only to evaluate how the accountability mechanism that occurred in the village government in managing BLT DD but also to measure the extent to which accountability has been implemented from the aspects of information, discussion, and information. To meet these two objectives, this study integrates the accountability framework from Bovens $(2007,2010)$ and the accountability cube from Brandsma and Schillemans (2013).

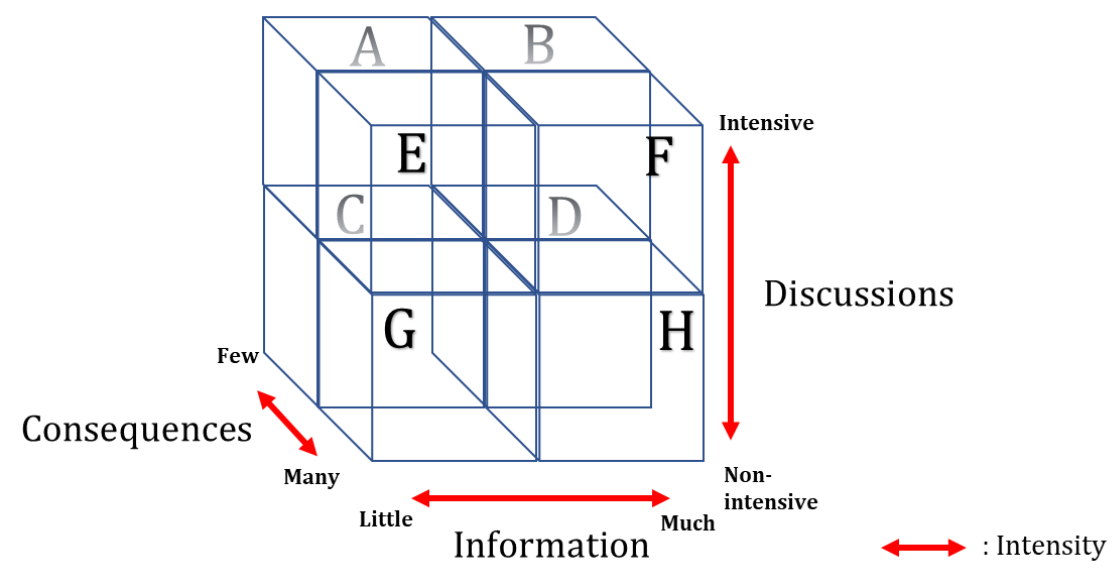

Fg. 2 Accountability Cube

Source: Brandsma \& Schillemans (2013)

According to the proponents of gender socialization theory, accountability in the organizations could be enhanced by optimizing the role of female members in the organizations. Arguably, compare to men, women pay more attention to the needs of people around them and more sensitive to the ethical issues that it constructs to the ideal figure of the supervisor to guide the organizations (Harris et al., 2019; Ibrahim \& Tomic, 2009; Komori, 2008). However, according to the theory of gender subtext, it is less likely for women to contribute optimally for the organizations since gendering is widely instilled in the organizations' day-to-day practices (Benschop \& Doorewaard, 1998; 2012). According to this theory, the hegemonic norms of masculinity subtly exist in the organizations that it defines the notion of ideal assignments, roles, and activities for men and women. Masculinity is associated with performing the production and commanding while femininity is highly associated with silence and obedience (Gherardi, 1994). Women play more roles in areas that are considered feminine. When women are involved in government organizations, for example, women tend to work more in "feminine" sectors such as health services, education, child and family welfare, and women's rights. Considering the pervasiveness of gendering norms in the organizations, it 
is less likely for female to enhance their potential within the organizations (Alkadry \& Tower; Bowling, et al.; Bullard \& Wright; Riccucci; in Smith, 2014).

Empowering the role of women in various fields can also be constrained when the level of women's education is still low. Studies from Indoria et al., (2019) and Sonowal (2013) showed there is a positive relationship between education and women's empowerment. If women are not educated, they will not be able to understand their rights and interests. Empowerment of women aims to increase employment opportunities, ownership of productive resources, increase participation in all sectors, increase living standards, independence, and selfconfidence.

Although education is a powerful tool for increasing women's empowerment, nevertheless, it is not enough. The number of women representations in the organization also plays a significant role. A study conducted by Hemson (2002) showed when the representation of women in an organization is minimal, women still experience inferiority even though their education level reaches the tertiary level. Women do not have enough voice to participate in decision making. Eventually, decision making is still dominated by men.

Research of gender in accounting practices indicate that this profession is still under the shadow of male domination. Several studies claimed that Accounting practice maintains masculine practices and downplayed the feminine values in which emotion is excluded from the practices (Broadbent, 1998; Haynes, 2017). Other studies by Dambrin \& Lambert (2012) and Mueller et al. (2011) highlighted that even though many women are now entering the accounting profession it is difficult for them to have career advancement in this area.

Moreover, Broadbent et al. (2008) described that to participate in enhancing organizations' accountability through the supervisory role, women are expected to possess masculine values to control the organizations while Mueller et al. (2011) argued that even though women legitimate themselves as possessing masculine traits, they are still experiencing frustration from the organizations' practices. These studies were mostly conducted in an Anglo-Saxon setting where the feminist movement has been quite advanced. Moreover, these studies were mostly conducted in a private-sector organization.

The research of women role in public sector accountability is rare and exclusively conducted in Anglo-Saxon setting i.e., Pedersen and Nielsen (2016) who found that female exhibited more bureaucratic accountability compared to male and Williamson et al. (2019) who described that in the public sector area, the progress of gender equality is more symbolical rather than substantive due to the limited measurement of gender equality policies reflected in Australian New Public Management. 
Considering the limited number of studies of women role in public sector accountability, this study is going to examine the role of women in public sector organization, especially in BPD, in constructing public sector accountability, especially BLT DD and COVID-19 related assistances accountability.

\subsection{Research framework}

This research employs the accountability framework as proposed by Bovens $(2007,2010)$ and Brandsma and Schillemans (2013), gender socialization and gender subtext theories. Bovens (2007) and Brandsma and Schillemans (2013) accountability assessment tools should be employed altogether to examine how actors engage with their forum in an accountability mechanism as well as to locate the accountability position of the actors. Bovens $(2007,2010)$ accountability mechanism nevertheless only portrays accountability as the relationship between actors and forums. There is a third party whose role is to oversight the implementation of accountability, which within the context of this research, this role is played by the BPD. Therefore, the framework employed in this research is as depicted in Figure 3.

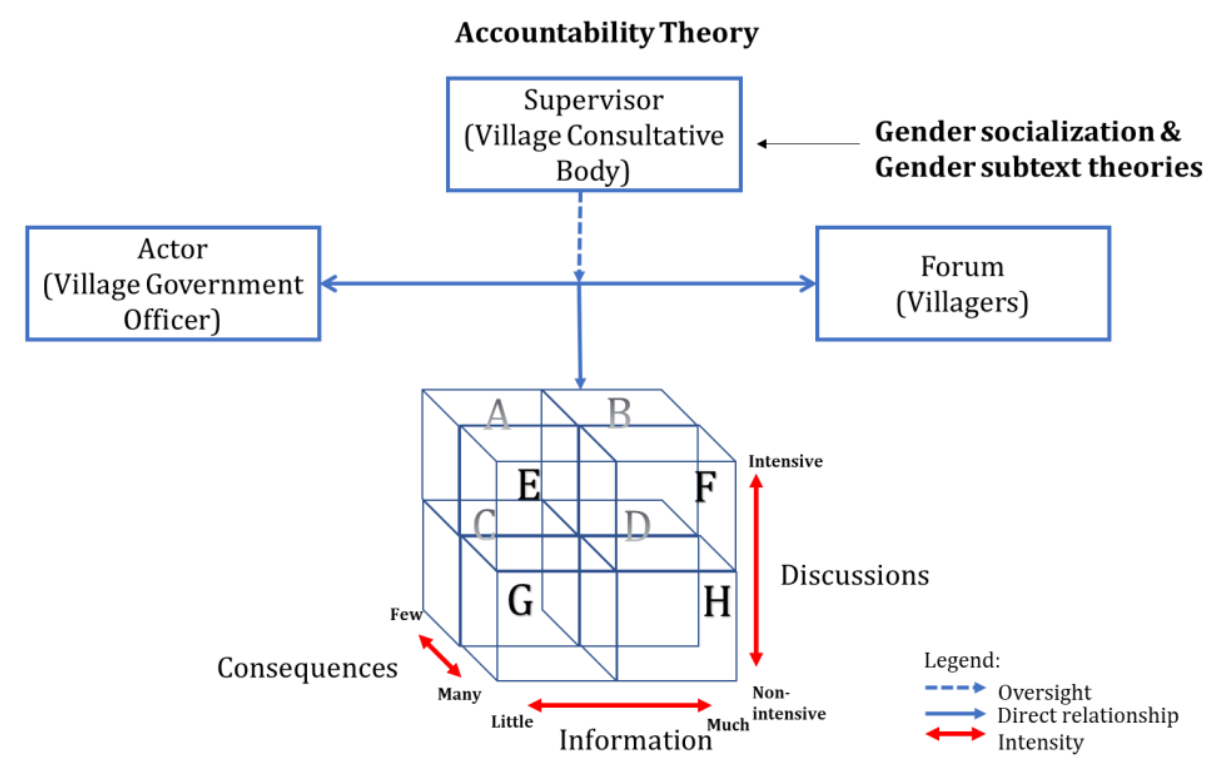

Fg. 3 Research Framework

Adapted from Bovens (2007, 2010), Brandsma and Schillemans (2013), Dawson (1992), and Benschop and Doorewaard $(1998,2012)$ by the authors

The accountability relationship between the actor (village government officers) and forum (villagers) is going to be examined in terms of the number of information discharged, the number of discussions held, and the consequences that are given by the villagers to the village government officers. The degree of each accountability element will determine the location of 
village accountability within the accountability cube. The role of BPD, especially it's female member, in shaping the accountability structure within each village, will then be examined.

\subsection{Previous studies in village fund accountability}

Studies related to the village fund program in Indonesia mainly focus on aspects of accountability as well as factors that influence accountability. Local Government interpreted accountability only to the extent of report submission while community considered that accountability was discharged as long as the infrastructure was available (Randa \& Tangke, 2015). The low education level of village citizen also contributes to the low level of public participation in village accountability since those village citizens were not critical enough to their government policy that results in lack of supervision and public participation (Mulyono, 2014).

Studies on accountability of Indonesian village fund mostly considered that accountability has been sufficiently performed if there is any information published by the Village Government. Disclosing the result of planned village fund allocation, village fund realization report, planned village programs, are considered as the act of giving proper accountability to the community (Kurrohman, 2015; Rakhman, 2019; Yunita \& Christianingrum, 2018). Furthermore, studies of Indonesian village fund accountability narrowly described the participation of community only to the extent of attending the village meeting that it is sufficient to claim that the accountability level has been enough (Rakhman, 2019; Savitri et al., 2019). The representatives only attend the annual village meeting (Musrenbangdes) by the village community such as the head of the neighbourhood, public figures, and representatives of community organizations. Yunita and Christianingrum (2018) found that several villages in Bangka Regency have established a grievance mechanism so that the villagers could channel their concerns to the village government. However, the grievance mechanism is not formally regulated by the law that it is doubtful that every village has a formal grievance mechanism system. Since it is more likely that public participation is still low and underdeveloped, the claims that the previous study has satisfactorily performed village fund accountability is potentially fallacious.

Furthermore, Savitri et al. (2019) claimed that the village fund accountability in Riau Province's villages had been performed since the village fund allocation planning process was already following the village regulation. Savitri et al. (2019) also stated that the timely submission of the village fund realization report to the Sub-district and Regent is considered as 
a mechanism to fulfil the accountability. Meanwhile, Rakhman (2019) suggested that the full village fund budget realization is the indicator of the village fund accountability.

Finally, most of the previous study on Indonesian village fund accountability did not implement a clear framework to examine accountability. Yunita and Christianingrum (2018) employ United Nation Development principles of accountability. However, this framework did not allow the examination of the stakeholders' view regarding the sufficiency of the information published and the reported realization report of APBDes (village budget). It also did not consider the intensity of discussion or debate incurred between village government and community regarding the filed complains.

It could be concluded that there are several limitations from the previous studies on village fund accountability. Accountability was still narrowly interpreted as a mere administrative process and compliance to regulation. Accountability in several villages is considered as useful only by the fact the report is submitted on time. This is contradicting with the fact that village fund accountability implementation in Indonesia is troublesome. Moreover, the intensity and dynamics of stakeholder participation also yet to be examined. The absence of clear research framework also makes the results of the studies are questionable. This study contributes to increasing village government accountability related to BLT DD and other government assistance by integrating accountability framework, accountability assessment with gender socialization and gender subtext theories.

\subsection{Research questions}

This research aims to answer the following questions:

a. How is the distribution process of BLT DD and other government assistance during the pandemic COVID-19?

b. How is the accountability mechanism and the accountability level of the village in terms of availability information required, discussions conducted, and consequences are given by the villagers?

c. How is the role of female BPD members in enhancing the accountability of the village fund and other government assistance?

\subsection{Research objectives}

Objectives of this research are:

a. To evaluate the distribution process of BLT DD assistance and other government assistance during pandemic COVID-19. 
b. To examine accountability mechanism and to determine the level of accountability in the villages.

c. To examine the roles of BPD and its female members in enhancing the accountability of the village fund.

\section{Methods}

This study applies a Case Study which defined as a research strategy that focuses on an intensive examination of a phenomenon in a real-life setting (Bryman, 2011). This case study explores phenomena that occurred in the village related to the distribution of government assistance during COVID-19 pandemic, which involved the villagers, village governments, and the village consultative body (BPD). Besides, the study is unique as it involved communities with poor knowledge on the supervision and the governance.

A qualitative descriptive research design was also implemented. The qualitative descriptive study allows the examination of "poorly understood phenomenon" from a naturalistic inquiry and facilitates a flexible implementation of the theoretical framework (Kim et al., 2017). This design is specifically useful to achieve the first research objective where no prior theoretical framework was available and also to supplement the analysis of second and third research objectives.

\subsection{Data collection}

There were 19 respondents participated in this study (Table 1). They were interviewed from 6 (six) different backgrounds: Village Head, Village Official, Head of BPD, female BPD member, Head of RT (neighbourhood), Head of RW (hamlet), and ordinary villagers. The respondents were interviewed during May - June 2020. Village Head and Village Officials are considered as the Actors, the Head of RT or RW and ordinary villagers are regarded as the Forum.

Table 1. Profile of the Respondents

\begin{tabular}{cclll}
\hline $\begin{array}{c}\text { Respondent } \\
\text { No. }\end{array}$ & $\begin{array}{c}\text { Interview } \\
\text { Date }\end{array}$ & Village & Position & Gender \\
\hline 1 & 31 May 2020 & Tegal & Villagers-Commoner & Female \\
2 & 02 June 2020 & Tegal & Village Official-Head & Male \\
3 & 02 June 2020 & Tegal & Village Official-Treasurer & Male \\
4 & 02 June 2020 & Tegal & BPD-Head & Male
\end{tabular}




\begin{tabular}{|c|c|c|c|c|}
\hline $\begin{array}{c}\text { Respondent } \\
\text { No. }\end{array}$ & $\begin{array}{c}\text { Interview } \\
\text { Date }\end{array}$ & Village & Position & Gender \\
\hline 5 & 02 June 2020 & Tegal & Villagers-Commoner & Female \\
\hline 6 & 02 June 2020 & Tegal & Villagers-Commoner & Male \\
\hline 7 & 04 June 2020 & Tegal & BPD-Member & Female \\
\hline 8 & 08 June 2020 & Tegal & Villagers-Head of RT & Male \\
\hline 9 & 09 June 2020 & Pasindangan & Village Official-Head & Male \\
\hline 10 & 10 June 2020 & Bojong & Village Official-Head & Male \\
\hline 11 & 10 June 2020 & Bojong & BPD-Head & Male \\
\hline 12 & 10 June 2020 & Bojong & Villagers-Head of RT & Male \\
\hline 13 & 10 June 2020 & Bojong & Villagers-Commoner & Female \\
\hline 14 & 11 June 2020 & Bojonggede & Village Official-Head & Male \\
\hline \multirow[t]{2}{*}{15} & 11 June 2020 & Bojonggede & Village Official-Community & Male \\
\hline & & & Welfare & \\
\hline 16 & 11 June 2020 & Bojonggede & Villagers-Head of RT & Male \\
\hline 17 & 11 June 2020 & Bojonggede & Villagers-Commoner & Female \\
\hline 18 & 22 June 2020 & Bojonggede & BPD-Head & Male \\
\hline 19 & 22 June 2020 & Bojonggede & BPD-Member & Female \\
\hline
\end{tabular}

Data was collected using 3 (three) different research instruments: (1) observations; (2) fieldwork; and (3) semi-structured interviews. In 2019, Bogor Regency had the most population in West Java, $12.10 \%$ (out of 49 million) of the population of West Java live in Bogor Regency (Media Indonesia, 2020). It is estimated that in 2020 Bogor Regency is the most densely populated in Indonesia with an estimated population of over 6 million.

Bogor Regency is also an area that has the highest original local government revenue in West Java Province with a value reaching 6.4 Trillion Rupiah in 2019 (Detik.com, 2019). Ironically, there are still many villages in Bogor Regency that are underdeveloped. According to Bogor Regency Statistical Bureau (2017), there were 395 million poor people (or 6.66\%) in Bogor Regency. In 2020, due to the COVID-19 pandemic, it is estimated that the number of poor people in Bogor Regency would be the highest in Indonesia, estimated to reach 6 million people (Republika.co.id, 2020). This means that accountability in the distribution of BLT DD assistance 
to reduce poverty in Bogor Regency, especially during the COVID-19 pandemic, needs special attention to be studied further.

Meanwhile, Cirebon Regency was also chosen in this study since its poverty rate is still high. In 2018, Cirebon Regency Statistical Bureau data showed 10.7\% (or 232,400) of Cirebon Regency residents were poor. In March 2019, the figure decreased by 0.43 per cent compared to 2018 (Cirebon Regency Statistical Bureau, 2018). However, the poverty depth index and the poverty severity index increased by 1.23 per cent in 2019 and 0.19 per cent in 2018 (Radarcirebon.com, 2020). This figure means that the average expenditure of the poor tends to be further away from the poverty line. Whereas, the expenditure inequality of the poor is also increased. Due to the Large-Scale Social Distancing that had been imposed, the fieldwork was postponed until June 2020. There are 3 (three) villages located in Bogor Regency: Tegal, Bojong, Bojonggede, and 1 (one) village located in Cirebon Regency: Pasindangan, that were chosen as the locations of fieldwork. These villages were selected to describe how accountability at the village level developed and in independent villages, especially in the distribution of BLT DD assistance during the COVID-19 pandemic. The interviews were conducted by two of the researchers both via phone or in-person.

\subsection{Demographic descriptions of the villages}

\subsubsection{Bojonggede village}

Bojonggede is a village located in Bogor Regency, Bojonggede Sub-district. Bojonggede is the capital of Bojonggede sub-district. As of 2017, there was 54.808 population in this village with a nearly balanced proportion (Bogor Regency Statistical Bureau, 2018a). This village is categorized as Independent Village according to 2020 Village Development Index (Ministry of Village Development of Disadvantaged Regions and Transmigration of Indonesia, 2020). This index reflects the level of village independency in three aspects: social resilience, economic resilience, and ecology/environment resilience (Ministry of Village Development of Disadvantaged Regions and Transmigration of Indonesia, 2020). Bojonggede Village does not have a website, but it has social media, Facebook. Before COVID-19 outbreak, this village used to update its activities on Facebook frequently. Moreover, most of the villagers staying in this area are mostly those who commute to Jakarta for work. Therefore, this village was awarded the status of Independent Village, which means this village could fulfil its own needs with very minimal help from the Government. 


\subsubsection{Tegal village}

Tegal is a village located in Bogor Regency, Kemang Sub-district. As of 2017, there was 19.040 population in Tegal Village with a nearly balanced proportion of men and women (Bogor Regency Statistical Bureau, 2018b). Tegal Village has the largest community in Kemang Sub-district. Almost $76 \%$ of its population work in the industry sector (Bogor Regency Statistical Bureau, 2018b). As of 2020, Tegal Village is considered as Developing Village according to Village Development Index (Ministry of Village Development of Disadvantaged Regions and Transmigration of Indonesia, 2020).

Tegal Village has one social media but no website as the source of information. However, this village rarely updated its social media, and there was no significant information about the village condition found. Little details on Tegal Village could be obtained through the Bogor Regency Youtube channel. In the uploaded video, Tegal Village Head claimed that the focused of Village Funds disbursement was to repair and build the infrastructure, mostly the road (Bogor Tegar Beriman TV, 2016b). Another observant of Tegal Village was also to restore the unsightly houses (Bogor Tegar Beriman TV, 2016b).

\subsubsection{Bojong village}

Bojong is a village located in Bogor Regency. It is the capital of Kemang Sub-district. As of 2017, there was 14.111 population in Bojong Village, which consisted of $51 \%$ male and $49 \%$ female. Almost $96 \%$ of the villagers took farming as their source of income (Bogor Regency Statistical Bureau, 2018b). According to the 2020 Village Development Index, Bojong Village was considered as Developing Village (Ministry of Village Development of Disadvantaged Regions and Transmigration of Indonesia, 2020).

This village does not have a specific website and social media to provide detail information about the village. However, from a video in Bogor Regency's Youtube Channel, the Village Head said that Bojong Village has the potential to develop their vegetable farming sector and their MSMEs businesses (Bogor Tegar Beriman TV, 2016a). However, he also said that there was still a lack of training and supervision for the MSME entrepreneurs (Bogor Tegar Beriman TV, 2016a).

\subsubsection{Pasindangan village}

Pasindangan is a village located in Cirebon Regency, Gunungjati Sub-district. Pasindangan Village's area was only $0,62 \mathrm{~km}^{2}$. As of 2018 , there were 5.425 residents in Pasindangan Village with a nearly balanced proportion of male and female (Cirebon Regency Statistical Bureau, 
2019). More than 15\% of families in this village were still live below the poverty line. This village also has the least productive harvest out of every village in Cirebon Regency. According to the 2020 Village Development Index, Pasindangan Village was considered as Developing Village (Ministry of Village Development of Disadvantaged Regions and Transmigration of Indonesia, 2020). There is no further information obtained about this village due to the lack of publicly available information.

\subsection{Data analysis}

Collected data were analysed using content and thematic analyses as proposed by (Braun \& Clarke, 2006; Krippendorf, 2004). This involved generating categories via open/close coding by applying NVIVO 12 Plus. Close coding means identifying and marking interesting items using a pre-established coding scheme, a theory driven as based on the themes raised by the accountability and the gender socialization theories. This is done so using the text search function found in NVIVO 12 Plus software. Whereas open coding means capturing and understanding the meaning of the data with some a priori idea about interesting themes as based on these two above theories, it is a data driven as based on some prior knowledge found in the theories.

To analyze the accountability mechanism, several codes related to the accountability framework were developed. The codes developed were: information, discussion, and consequences aspects between the accountable actor and forum as well as, decisions, outputs, and performance found in gender studies raised earlier. On the other hand, to explain the process of BLT DD and other Government assistance distribution and to explain the roles of female BPD member in village accountability, the emerging themes were developed through the open coding process.

\section{Results and Discussion}

\subsection{Research findings}

\subsubsection{Distribution process of BLT DD assistance}

The distribution of BLT DD assistance is initiated from a joint meeting attended by the village head, village officials, BPD head, heads of RT, heads of RW to determine village fund allocated to the BLT DD assistance. After the allocation of BLT, DD assistance has been determined, the village meeting decided the quota recipients by dividing the fund allocated to BLT DD assistance with the amount of assistance received by each recipient. Once the quota recipients have been established, this quota is allocated equally to each RT in the village. The quota was divided 
based on the number of RTs in the village, so that each RT receive an equal number of recipients (Respondent \#15, 2020, Respondent \#4, 2020).

Based on the agreed number of recipients in each RT, the RT heads would select the villagers who are entitled to receive the assistance. The villagers who received BLT DD assistance were those who were affected by the economy due to the COVID-19 pandemic and had never received assistance before from the government. This is done so that no one gets double assistance from the government. The criteria commonly used in selecting potential beneficiaries are those who are economically affected by the COVID-19 pandemic, such as being laid off from work or losing their livelihoods due to the COVID-19 pandemic (Respondent \#4, 2020, Respondent \#10, 2020).

RT heads were deployed to select potential beneficiaries by receiving input from economically affected residents, observing, and interviewing the candidates. The RT heads then asked the candidates to submit photocopies of their ID cards and family cards as an administrative requirement for submitting beneficiary nominations to the village government. Furthermore, the list of proposed beneficiaries in each RT will be submitted to the respective RW head for approval (Respondent \#8, 2020). The RW heads then submitted a list of proposed beneficiaries to the village apparatus for final approval from the Village Head and the Head of the BPD.

The team assigned to verify the list of potential beneficiaries varies from village to village. In 1 (one) village, data verification was assigned to the People's Welfare Division in the village government. In other villages, the verification process is assigned to a special task force consisting of a combination of the village government, BPD, heads of RT and RW and representatives of youth organizations (Respondent \#4, 2020).

After the list of potential recipients of BLT DD assistance being verified, the list was approved by the village head and the head of the BPD. The distribution process of BLT DD assistance is described in Figure 4. 


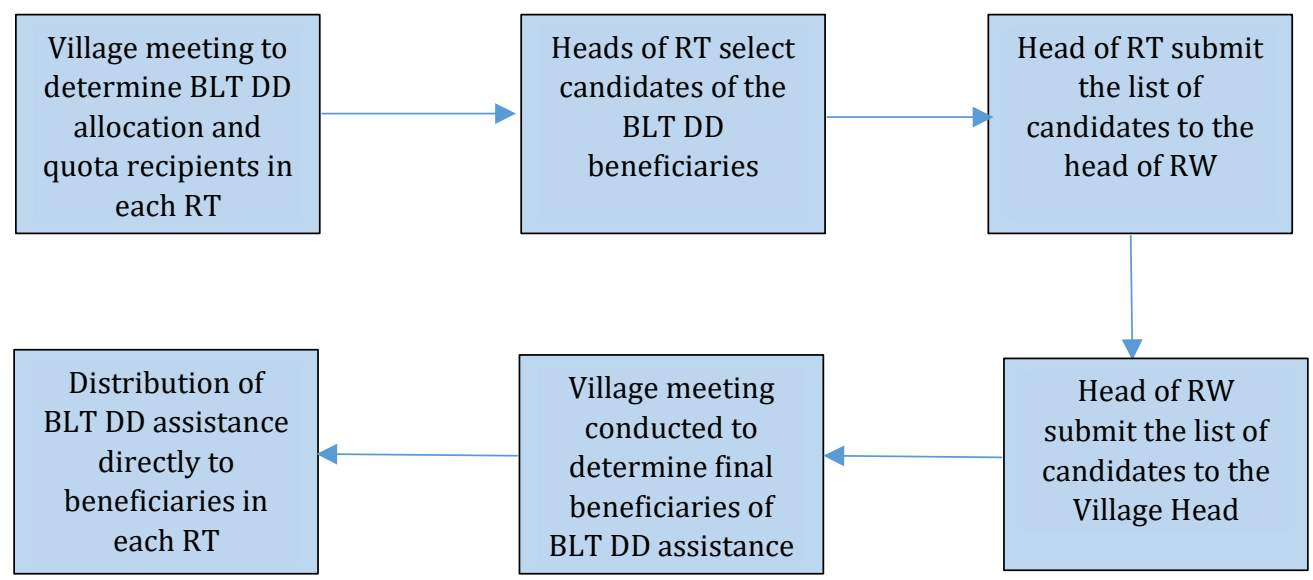

Fg. 4 Distribution Process of BLT DD Assistance

\subsubsection{Information, discussion, and consequences}

Respondents who came from ordinary villagers claimed that they were completely unaware of any information regarding BLT DD assistance or other government assistance from village officials (Respondent \#1, 2020 and Respondent \#6, 2020).

“... There was no information at all from the village officials about this BLT DD, social aid or other government assistance. Even the use of village fund allocation which is said to be worth 1 billion was not informed at all by the village government to the residents here ..." (Respondent \#1, 2020)

In managing village funds in general, the four (4) Village Heads said that they were accountable and transparent because they had announced the plan to use village funds in a large banner displayed in front of the village office. However, based on field observations by the authors, only one village has succeeded in showing evidence of the announcement of the village fund budget to villagers. The authors further asked village heads about other forms of accountability that have been carried out in managing village funds. Two village heads said that they published accountability reports for the realization of village funds to the Sub-District office (Respondent \#2, 2020, Respondent \#14, 2020). However, the accountability report is not available to the public. Another Village Head responded it is not required to report the realization of the programs since some of the villagers were directly involved in the construction of the projects held by the village government.

“... we don't need to inform them. They already know the progress of the project. For instance, there was a road paving project. We assigned it to 20 to 30 villagers to work in this project. They have the required skills, and we paid them. They knew it ..." (Respondent \#10, 2020)

The village meetings were attended only by village officials, BPD, and representatives of village community organizations (i.e., village youth organization, family welfare program, religious leaders, village community empowerment institution, and others). 
"... If there is a village meeting, residents have never been invited. Only village officials were invited ..." (Respondent \#6, 2020).

Discussion with the villagers to be transmitted via the head of neighborhood (head of RT and RW) with the expectation that the head of neighborhood will disseminate the information to the villagers and will also gain aspiration from the villagers. However, in practice, the head of the neighborhood seemed to ignore to discuss with the villagers in gaining the aspirations because they assumed that the villagers are lack of understanding on village fund issues.

“... For example, if the residents had an opinion about infrastructure's development, but usually their opinion not as much as the opinion from the RT's officials. They (the residents) not really understand about village fund ..." (Respondent \#16, 2020).

The BPD may issue a note of objection that request the village head to provide explanations to BPD. However, the BPD has always been satisfied by a merely verbal explanation by the village government without needing to issue the note of objection.

“... BPD may issue a note of objection to the implementation of previous year APBDes... The objection note only contains a request for an explanation of the development carried out by the village head. If that explanation is acceptable, it does not matter... I have never issued a letter of objection because the explanation from the village head was already adequate ..." (Respondent \#18, 2020).

Minimum discussion occurred when the BPD and the village government were not in a good term. The head of the BPD was not asked for approval by the village government for the village fund budget submitted to the District Office. Instead, the village government unilaterally stated that the proposed village fund budget had been approved by the Head of the BPD (Respondent \#11, 2020).

"... I once reported it to the Head of the Development Section in the Sub-District office. I said this APBDes should be discussed and agreed first with the BPD. But I wonder why my signature was not there as a sign of approval from the BPD. How come I did not know about the APBDes? It turned out that in the APBDes, it was only written that this APBDes had been agreed by the Village Head and BPD, without my signature as approval on it ..." (Respondent \#11, 2020).

Complaints from the villagers were conveyed informally through the head of the neighborhood or word-of-mouth.

“... There are no complaints from residents in this village. Whoever finally gets the BLT DD assistance, whether they are rich or poor, we took it all for granted. Even if we want to complain, we do not know who to complain to? ..." (Respondent \#5, 2020).

\subsubsection{The roles of the female BPD members}

The involvement of women members of the BPD in providing consequences for misconducts that may be carried out by the village government was not apparent. This is also since female 
BPD members are not involved in criticizing policies and overseeing the village government. Female BPD members are only following and submit to whatever the Chairman of the BPD has decided.

In each village, there is a representation of female BPD membership, as it is mandated by the Ministry of Home Affairs No. 110 the Year 2016. However, the number of women representative is at minimum, only one female member in each BPD. Moreover, the female BPD members were assigned in feminine-related tasks, such as secretary and supervisor to maternal, children, family and health programs. The female BPD members were not involved with masculinerelated tasks, such as supervising infrastructure development, leading the BPD meetings and other village meetings.

“... I often provide input regarding health issues since I am a BPJS insurance volunteer. Because I often experience there are still a lot of mothers who do not have BPJS insurance, are pregnant and have a history of complications. Later it will relate to the village government as well because to register for BPJS membership, a certificate from the village office is required. I socialized it through the Posyandu (maternal and child health services) so that residents register for BPJS insurance before it is used for health care needs ..." (Respondent $\# 19,2020$ )

“... During the meetings, I just responsible for taking notes. The Chairman was leading and dominating the discussions. I could have more involved during the discussions, however, men are always put first. I am afraid that my thoughts and opinions would not be considered because I am just a woman ..." (Respondent \#7, 2020).

\subsection{Transparency dilemma in distributing BLT DD assistance}

The village governments were facing a dilemma in disclosing the distribution process of BLT DD assistance. This occurred due to a limited amount of assistance that might not be sufficient to be allocated to all eligible beneficiaries in the village. Therefore, they were forced to equally distributed the quota of assistance to each neighborhood (RT), regardless of the actual number of eligible beneficiaries. This is worsened by the fact that there were unclear and complicated criteria in determining the eligibility of beneficiary.

Due to these complexities in distributing assistance, i.e., shortage in funding and unclear beneficiary criteria, the list of beneficiaries of this assistance was not made public. According to Respondent \# 2 (2020), this was done to avoid commotion in the community and to avoid further questions form the villagers who were not receiving the assistance. The BLT DD assistance was handed over directly to the beneficiaries using different strategies. The village officials handed over aid to the recipient's residence, accompanied by the heads of the RT, RW and BPD as explained by Respondent \#2 (2020). Meanwhile, in another village, the BLT DD assistance was handed over by inviting beneficiaries to take assistance directly at the village office. According to the acknowledgment of the Respondent \# 10 (2020), this was done to avoid negative perceptions from the community towards the heads of RT. If the heads of RT 
distributed their assistance to residents, some residents would think that the assistance had been taken for the personal benefit of the RT and RW heads.

This transparency dilemma could be explained using accountability mechanism (Bovens, 2007, 2010) where discussions among the actor and the forum were limited, therefore, the distribution of the assistance was disordered. Should the village government invite the villagers to have an open discussion on the distribution of the limited amount of BLT DD assistance, this transparency dilemma might not have occurred. However, as Bovens (2010) mentioned, in the absence of discussions, at least the actor should provide sufficient explanations (information) to the accountable forum. Consequently, and in-line with Brandsma and Schillemans (2012), this has made the accountability level of these 4 (four) villages positioned in quadrant $\mathrm{C}$ of the accountability cube, i.e., low level of information and discussion.

\subsection{Low accountability level and gendering role in female BPD members}

The 4 (four) villages observed in the study were indicating a low level of accountability in terms of information provided to the forum, discussions held, and consequences given to the actors.

\subsubsection{Information}

Information disseminated to the accountable forum is still limited in all of the 4 (four) villages, i.e., in terms of media outreach, frequency, and the contents of information made available to the forum. This lack of information has made villagers have limited information in criticizing the implementation of accountability for village funds. Low-level information disclosed by the Village Governments to their constituents results in the low level of constituents' participation in supervising the Village Government. This may result in any misconduct behavior of the village officials might be abandoned and unpunished. Further, the lack of information disables the villagers to participate optimally in their village development as they do not have a comprehensive picture of the condition of their villages. The mandate of the Ministry of Village Regulation No. 7 of 2020 states that village governments must announce priority plans for the use of village funds to the public using all media accessible to the public.

The lack of information from the Village Government in managing village funds is not only experienced by ordinary villagers. The BPD as the supervisory body for the village government in one of the villages interviewed also experienced difficulties in accessing the village fund management accountability report. The Village Government does not submit an accountability report for the realization of village funds to the Head of the BPD for approval but instead 
submits it directly to the District Office (Respondent \#11, 2020). This turned out to be triggered by a disharmonious relationship between the Village Head and the Head of the BPD. The Head of the BPD has reported the incident to the District Office, but there has been no follow-up from the District Office to the Village Government.

The role of female BPD members in demanding accountability and in delivering information on village fund management is not evident from this study. This is because female members of the BPD are not directly involved in monitoring activities over the village government. Besides, the two female BPD members who participated as resource persons in this study admitted that they were still new to the BPD structure, so they did not know their rights and obligations as BPD members in supervising the Village Government.

\subsubsection{Discussions}

Discussions on the accountability of the assistance between the actors and the forums are still inadequate since ordinary villagers were not invited in Village Meetings and only represented by the Head of Neighborhood. The assumption that villagers were unable to understand issues in village fund management was triggered by the fact that the average level of education of villagers is still low. However, this should not be an excuse for not transmitting information to villagers by the heads of RT / RW, who should be acting as the representatives voicing the aspirations of the ordinary villagers. If this condition continues, it will worsen accountability in the management of village funds. Villagers should be taught to be knowledgeable about their rights and be more actively involved in criticizing the management of village funds.

The mandate of the Ministry of Home Affairs Regulation No. 20 of 2018 requires village budgets to be approved by the BPD before being proposed to the District Office. However, there was a case where the BPD was not involved in discussing the village budget and the approval from BPD was absent. As a result, the village budget might not reflect the aspirations of wider constituents as the BPD responsible in conveying villagers' aspiration to the village government. This minimum discussion resulted in reduced opportunities for the community to ask questions, channel their aspirations, and provide consequences for the accountability made by the Village Government. The Village Government dominated the decision-making process.

\subsubsection{Consequences}

The consequence is given to the village officials by the BPD and villagers due to their performance (whether satisfactory or less satisfactory) in managing village fund was almost 
none. The BPD head claimed that should the village head fail to execute the intended programs, they would issue a note of objection. However, the note of objection was less powerful in reprimanding the village government. Further, the BPD shas never issued the letter to request a formal (written) explanation from the village government since they were already satisfied with the performance of the Village Government.

The villagers were also reluctant to provide consequence and to challenge the village government should they fail to perform the programs. This is due to the fact there was no formal channel and mechanism to address complaints so that there is no guarantee that their complaints will be followed up further. Moreover, the BPD efforts to engage more with the villagers to obtain their aspirations were still minimum. Thus, the villagers were unaware that they could channel their aspirations through BPD. In the absence of consequence, this has caused the village government to repeat the same misconduct behaviour since they gain no lessons from their previous actions.

\subsection{Gendering roles of the female BPD members}

Women are mandated to be represented in the BPD membership as they have potentials in enhancing village accountability by performing supervisory roles. However, their potentials were suppressed by the hegemonic masculinity in the organization. As a result, women are only the followers of the male BPD members and have limited roles in enhancing village accountability. Furthermore, minority representativeness in the organization shas made female BPD member feel inferior to the male members. Women's representation in the BPD membership is also minimal, only 1 out of a total of 9 BPD members. The lack of female membership in the BPD has also made female members of the BPD less vocal than male members. The discussions were dominated by male BPD chairmen and male BPD members. These findings are in line with gender subtext theory as proposed by Benschop and Doorewaard $(1998,2012)$ where there is a subtle gendering in the organizations which have claimed to adopt gender equality. Moreover, the fact that minority female representation in BPD shas made them experience inferior is also aligned with Hemson (2002).

Besides, female BPD members are mostly assigned to administrative tasks behind the desk, for example as secretary of the BPD, who take more notes rather than being actively involved in discussions or meetings with the village government (Respondent \# 4, 2020). Female BPD members are also only involved in feminine activities such as maternal and child health services (Posyandu), education, and health insurance issues (BPJS Kesehatan) (Respondent \#19, 2020). Activities that require physical supervision, such as supervision of the implementation of 
village infrastructure projects, are mostly carried out by male BPD heads and members (Respondent \#18, 2020). These findings are consistent with the gendering subtext theory (Benschop \& Doorewaard, 1998; 2012) where masculinity and femininity subtly exist in the organizations that it defines the roles and activities of men and women.

Gender socialization theory was not applicable in the context of female supervisory role in BPD due to the pervasiveness of gendering in the BPD. As a result, lack of roles and opportunities given to the female members have caused female BPD members reluctant to express their thoughts and opinions. They have a lack of confidence, motivation, knowledge, and leadership in challenging their roles in BPD due to cultural and religious factors where women should always obey men. However, the male members of BPD lack of knowledge regarding their roles, tasks and responsibilities in conducting village supervision since there was no training provided for them, as indicated by Respondent \#18 (2020). Therefore, male BPD members could not serve as role models for female BPD members.

The villages were failed to enhance the roles of female BPD member in enhancing village accountability. This happened since male-dominated culture is very pervasive in the village organizations. Moreover, this worsened by the less-supportive regulation that only required very minimum representation of women in BPD membership. In the patriarch regime, women empowerment should be supported by a sound and clear regulation regarding the women representativeness in the organization. It is expected that women would have more confident in engaging with supervisory activities which were perceived as masculine activities. Furthermore, training in enhancing the capacity of BPD members are required to increase their skills in performing supervisory tasks confidently.

\subsection{Positioning the accountability level and the roles of female BPD members}

The result of this study contended the findings of Kurrohman (2015), Rakhman (2019), and Yunita and Christianingrum (2018) where the accountability level of village fund was already sufficient. This study found that the information provided to the accountable forum was limited. The village government perceived that they were not obliged to provide information to the village community. Meanwhile, Bovens (2010) argued that the accountable relation works if the accountable actors are, or at least feel obliged to provide sufficient information to the accountable forum.

Rakhman (2019) and Savitri et al. (2019) argued that the discussion held by the village community was sufficient since participation to attend the village meetings were high. However, this study found that participation in the village meetings haswas limited to the 
representative of the village community. Ordinary villagers did not have the opportunity to attend the village meetings. The aggregative discussion which was attended by the representative forum is not adequate to claim that the accountability level in terms of the discussion held is sufficient since Bovens (2010) argued that discussions with accountable forum should involve all elements affected by the decisions made by the actors.

The previous study from Yunita and Christianingrum (2018) suggested that there was a grievance mechanism to channel public complains, and thus, it indicates a sufficient level of accountability. Though the grievance mechanism was discussed in their study, however, the mechanism is not standardized as it is not formally regulated, therefore, it may not be applicable in other villages. This study contributes to the discussions on consequences by not only examining the existence of grievance mechanism but also examining the existence of formal or informal consequences in judging performance (satisfactory or less satisfactory) and the lesson learned obtained from the consequences given as proposed by Bovens $(2007,2010)$. It was found that consequences could be given by the BPD and representative of community exclusively. However, since the ordinary villagers did not invite to the village meetings and there was no formal grievance mechanism established, they could not provide consequences to the village government. On the other hand, consequences provided by the BPD and the representative of the community were minimum, therefore, no lesson learned obtained by the village government to enhance their accountability and governance. This condition is worsened by the constituents apathy caused by several factors, i.e., no follow-up actions from village government on the complains addressed by the villagers, minimum formal channel for addressing villagers' complains and for providing information to the villagers. As based on the above findings, it is concluded that the accountability cube of 4 (four) villages lies in quadrant C.

The role of BPD female members in criticizing information, discussions and the consequences for misconduct that may be carried out by the village government is also very minimal. Several factors were identified in this study. First, female members of the BPD are only involved in feminine roles and activities and are not involved in the supervisory role of the village government. Second, the number of women's representation in BPD membership is also minimal. This makes women members of the BPD have insignificant voice compared to members of the BPD men. Eventually, female BPD members are only perceived as a complimentary and non-essential part of village governance.

This study has 2 (two) significant contributions by applying accountability mechanism (Bovens, 2007; 2010), accountability cube (Brandsma \& Schillemans, 2012), gender 
socialization theory (Dawson, 1992), and gender subtext theory (Benschop \& Dooreward, 1998; 2012). First, not only that the study strengthened the discussion on the accountability of the public sector institutions (i.e., less accountable institutions), this study has contributed by providing a systematic and solid measurement of the public sector institutions accountability. Second, this study explored female supervisory roles in enhancing accountability. The result of this study is summarized in Figure 5.

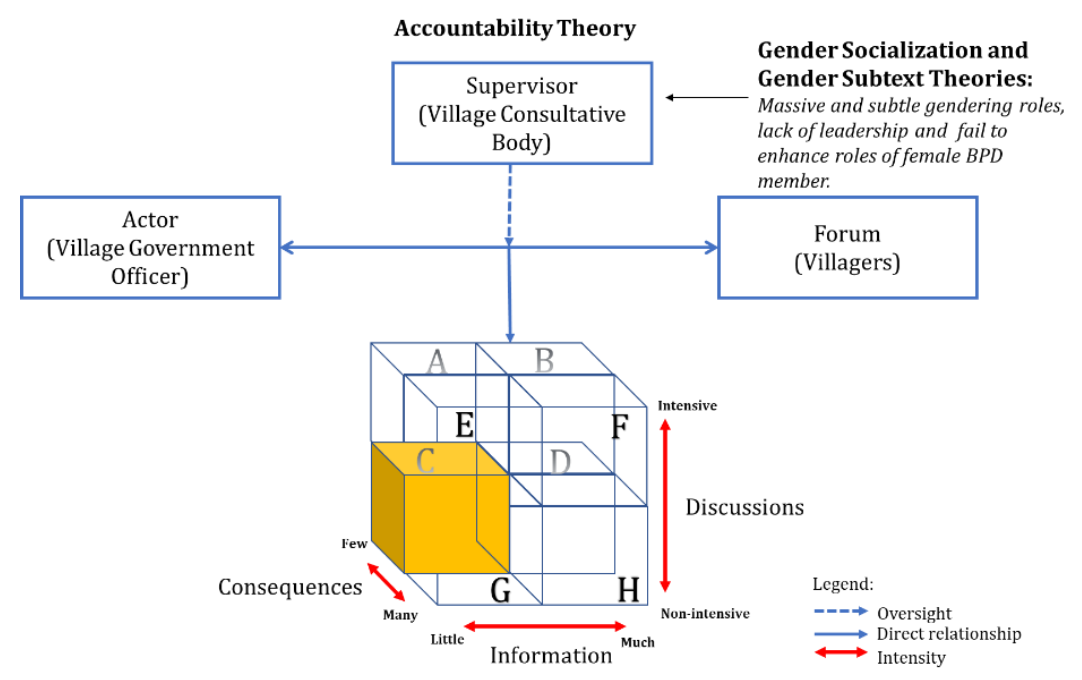

Fg. 5 Accountability Level and The Roles of Female BPD Member

\section{Conclusion}

This study contributes to providing an integrated framework that is useful for studies in examining accountability and gender role in enhancing accountability. This study found that the villages observed have provided limited information regarding the BLT DD assistance and other COVID-19 related assistance. Consequently, the villagers did not have sufficient information to participate in the village decision-making process and to criticize BLT DD assistance and other COVID-19 related assistance distribution process. The villagers were not invited to any village meetings that it prevents them to provide inputs and consequences to the village government. As a result, the level of accountability regarding the information provided, a discussion held, and consequences are given are at the minimum level (in quadrant C).

It is also found that the roles of female BPD members in enhancing accountability were insignificant due to the pervasiveness of gendering practice in village organizations. Therefore, female BPD members roles in enhancing village accountability are yet to be optimal. These findings contradict gender socialization theory that women with all their feminine traits are suitable and potential to perform supervisory tasks in guiding the organization. However, these findings are aligned with gender subtext theory that segregation of duties based on 
masculinity and femininity are apparent in the village organization. Women were not part of the governance process but rather regarded as non-essential" complementary" part of village governance.

\section{Acknowledgements}

The authors wish to express our gratitude to the Directorate of Research and Development, Universitas Indonesia for awarding the grant for international indexed publication (PUTI Q3) to the authors so that this publication can be carried out well. The authors would also like to thank the Dinas Kesbangpol Bogor Regency for issuing permits to carry out the field study of this research. Last but not least, we would also like to thank all respondents from the Village Officials, BPD and villagers in Tegal Village, Bojong Village and Bojonggede Village, Bogor Regency, and in Pasindangan Village, Cirebon Regency who have been very supportive and been actively participating in addressing our research questions and providing valuable inputs to this study.

\section{Author Contribution}

Desti Fitriani, Elvia R Shauki, and Siti Czafrani Pratiwi originally conceived the presented idea. Elvia R Shauki verified the analytical methods. All authors investigate the outbreak of COVID-19 and supervised the findings of this work that also include Village Fund Direct Cash Assistance (BLT DD) distribution. All Authors discussed the results and contributed the final manuscript.

\section{References}

Aucoin, P., \& Heinzman, R. (2000). The dialectics of accountability for performance in public management reform. International Review of Administrative Sciences, 66(1), 45-55. https://doi.org/10.1177\%2F0020852300661005

Badan Pusat Statistik (2020, July 25). Persentase Penduduk Miskin Maret 2020 naik menjadi 9,78 persen. https://www.bps.go.id/pressrelease/2020/07/15/1744/persentase-pendudukmiskin-maret-2020-naik-menjadi-9-78-persen.html

BBC News Indonesia. (2020, June 24). Covid-19: 'Indonesia berpotensi resesi' - dampak ekonomi 'jauh lebih berat' ketimbang krisis moneter 1998. https://www.bbc.com/indonesia/indonesia-53152994 
Benschop, Y., \& Doorewaard, H. (1998). Six of one and half a dozen of the other: The gender subtext of Taylorism and team-based work. Gender, Work \& Organization, 5(1), 5-18. https://doi.org/10.1111/1468-0432.00042

Benschop, Y., \& Doorewaard, H. (2012). Gender subtext revisited. Equality, Diversity and Inclusion: An International Journal, 31(3), 225-235.

https://doi.org/10.1108/02610151211209081

Beritabeta.com (2020, June 9). https://beritabeta.com/news/lintas-daerah/dimasalahkanpenyaluran-blt-dd-batujungku/

Bogor Regency Statistical Bureau. (2017). Garis Kemiskinan dan Penduduk Miskin di Kabupaten Bogor, 2010-2015. https://bogorkab.bps.go.id/statictable/2017/05/18/10/gariskemiskinan-dan-penduduk-miskin-di-kabupaten-bogor-2010-2015-.html

Bogor Regency Statistical Bureau. (2018a). Kecamatan Bojonggede dalam Angka 2018.

https://bogorkab.bps.go.id/publication/2018/09/26/e8aa3364feea4b82a294df2b/keca matan-bojong-gede-dalam-angka-2018.html

Bogor Regency Statistical Bureau. (2018b). Kecamatan Kemang dalam Angka 2018. https://bogorkab.bps.go.id/publication/2018/09/26/7b99073701d40362dabdff90/kec amatan-kemang-dalam-angka-2018.html

Bogor Tegar Beriman TV. (2016a). Berkunjung ke Desa Bojong Kecamatan Kemang. https://www.youtube.com/watch?v=8ZuKktvXpMU

Bogor Tegar Beriman TV. (2016b). Potensi dan Kemajuan Desa Tegal Kecamatan Kemang. https://www.youtube.com/watch?v=z-fCy4XH93c

Bovens, M. (2007). Analysing and assessing accountability: A conceptual framework1. European Law Journal, 13(4), 447-468.

https://doi.org/10.1111/j.1468-0386.2007.00378.x

Bovens, M. (2010). Two concepts of accountability: Accountability as a virtue and as a Mechanism. West European Politics, 33(5), 946-967. https://doi.org/10.1080/01402382.2010.486119

Brandsma, G. J., \& Schillemans, T. (2013). The accountability cube: Measuring accountability. Journal of Public Administration Research and Theory, 23(4), 953-975. https://doi.org/10.1093/jopart/mus034

Braun, Virginia \& Clarke, Victoria. (2006) Using thematic analysis in psychology, Qualitative Research in Psychology, 3:2, 77-101. https://doi.org/10.1191/1478088706qp063oa 
Broadbent, J. (1998). The gendered nature of "accounting logic": pointers to an accounting that encompasses multiple values. Critical Perspectives on Accounting, 9(3), 267-297. https://doi.org/10.1006/cpac.1997.0158

Broadbent, J., Dietrich, M., \& Laughlin, R. (1996). The development of principal-agent, contracting and accountability relationships in the public sector: conceptual and cultural problems. Critical Perspectives on Accounting, 7(3), 259-284.

https://doi.org/10.1006/cpac.1996.0033

Broadbent, J., Kirkham, L., \& Parker, L. D. (2008). Strategic management and accounting processes: acknowledging gender. Accounting, Auditing \& Accountability Journal, Vol. 21 No. 4, pp. 611-631. https://doi.org/10.1108/09513570810872941

Bryman, A. (2011). Business Research Method (3rd ed.). Oxford University Press.

Cirebon Regency Statistical Bureau. (2018). Jumlah Penduduk Miskin (Ribu Jiwa), 2017-2019. https://cirebonkab.bps.go.id/indicator/23/40/1/jumlah-penduduk-miskin.html

Cirebon Regency Statistical Bureau. (2019). Kecamatan Gunungjati dalam Angka 2019. https://cirebonkab.bps.go.id/publication/2019/09/26/d2d87da33d447f23e2255ede/k ecamatan-gunungjati-dalam-angka-2019.html

Dambrin, C., \& Lambert, C. (2012). Who is she and who are we? A reflexive journey in research into the rarity of women in the highest ranks of accountancy. Critical Perspectives on Accounting, 23(1), 1-16. https://doi.org/10.1016/j.cpa.2011.06.006

Dawson, L. M. (1992). Will feminization change the ethics of the sales profession?. Journal of Personal Selling \& Sales Management, 12(1), 21-32.

https://www.tandfonline.com/doi/abs/10.1080/08853134.1992.10753895

Detik.com. (2019, October 8). Ironi Kabupaten Bogor: PAD Tertinggi di Jabar, Banyak Desa Tertinggal. https://news.detik.com/berita/d-4738366/ironi-kabupaten-bogor-padtertinggi-di-jabar-banyak-desa-tertinggal

Devas, N., \& Grant, U. (2003). Local government decision-making-citizen participation and local accountability: some evidence from Kenya and Uganda. Public Administration and Development: The International Journal of Management Research and Practice, 23(4), 307316. https://doi.org/10.1002/pad.281

Gherardi, S. (1994). The gender we think, the gender we do in our everyday organizational lives. Human Relations, 47(6), 591-610. https://doi.org/10.1177/001872679404700602

Gray, A., \& Jenkins, B. (1993). Codes of accountability in the new public sector. Accounting, Auditing \& Accountability Journal, 6(3). https://doi.org/10.1108/09513579310042560 
Harris, O., Karl, J. B., \& Lawrence, E. (2019). CEO compensation and earnings management: Does gender really matters? Journal of Business Research, 98(February 2018), 1-14. https://doi.org/10.1016/j.jbusres.2019.01.013

Haynes, K. (2017). Accounting as gendering and gendered: A review of 25 years of critical accounting research on gender. Critical Perspectives on Accounting, 43, 110-124. https://doi.org/10.1016/j.cpa.2016.06.004

Hemson, D. (2002). Women Are Weak When They Are Amongst Men ': Women 's Participation in Rural Water Committees in South Africa. Agenda: Empowering Women for Gender Equity, 52, 24-32. https://doi.org/10.2307/4066469

Ibrahim, N., \& Tomic, I. M. (2009). Managers ' Attitudes Toward Codes of Ethics: Are There Gender Differences ? Journal of Business Ethics, 90(2009), 343-353. https://doi.org/10.1007/s10551-010-0428-y

Indoria, D., Ram, M., \& Solanki, R. L. (2019). Role of Education in Women Empowerment and Entrepreneurship. International Journal of Current Microbiology and Applied Sciences, 8(05), 72-79. https://doi.org/10.20546/ijcmas.2019.805.010

Jantz, B., Christensen, T., \& Lægreid, P. (2015). Performance Management and Accountability: The Welfare Administration Reform in Norway and Germany. International Journal of Public Administration, 38(13-14), 947-959. https://doi.org/10.1080/01900692.2015.1069838

Jantz, B., \& Jann, W. (2013). Mapping accountability changes in labour market administrations: From concentrated to shared accountability? International Review of Administrative Sciences, 79(2), 227-248. https://doi.org/10.1177/0020852313477764

Kim, H., Sefcik, J. S., \& Bradway, C. (2017). Characteristics of qualitative descriptive studies: A systematic review. Research in Nursing \& Health, 40(1), 23-42.

https://doi.org/10.1002/nur.21768

Komori, N. (2008). Towards the feminization of accounting practice. Accounting, Auditing \& Accountability Journal, 21(4), 507. https://doi.org/10.1108/09513570810872905

Kompas.com. (2020, June 19). BLT Rp 600.000 Hanya Dibagikan Rp 150.000, Warga Laporkan Kepala Desa ke Kejaksaan.

https://regional.kompas.com/read/2020/06/19/08261781/blt-rp-600000-hanyadibagikan-rp-150000-warga-laporkan-kepala-desa-ke?page=all 
Krippendorff, K. (2004). Reliability in content analysis: Some common misconceptions and recommendations. Human Communication Research, 30(3), 411-433.

https://doi.org/10.1111/j.1468-2958.2004.tb00738.x

Kurrohman, T. (2015). Accountability of planning on village fund allocation in osing community in Banyuwangi [Conference proceeding]. International Conference on Accounting Studies (ICAS) 2015, Aug 17-20, 2015. http://repo.uum.edu.my/id/eprint/17588

Lerner, J. S., \& Tetlock, P. E. (1999). Accounting for the effects of accountability. Psychological Bulletin, 125(2), 255-275. https://doi.org/10.1037/0033-2909.125.2.255

Media Indonesia. (2020, September 7). Angka Kemiskinan di Kabupaten Bogor Diprediksi Meningkat. https://www.medcom.id/nasional/daerah/RkjB3GRk-angka-kemiskinan-dikabupaten-bogor-diprediksi-meningkat?p=all

Ministry of Village Development of Disadvantaged Region and Transmigration of Indonesia. (2019). Tentang Indeks Desa Membangun.

http://idm.kemendesa.go.id//view/detil/1/tentang-idm

Ministry of Village Development of Disadvantaged Region and Transmigration of Indonesia. (2020). Indeks Desa Membangun. https://idm.kemendesa.go.id/idm_data

Mueller, F., Carter, C., \& Ross-Smith, A. (2011). Making sense of career in a Big Four accounting firm. Current Sociology, 59(4), 551-567. https://doi.org/10.1177/0011392111402734

Mulyono, S. P. (2014). Sinergitas Penyelenggaraan Pemerintahan Desa Pasca Pemberlakuan UU NO. 6 Tahun 2014 Tentang Desa. Masalah-Masalah Hukum, 43(3).

https://doi.org/10.14710/mmh.43.3.2014.438-444

Pedersen, M. J., \& Nielsen, V. L. (2016). Manager-Employee Gender Congruence and the Bureaucratic Accountability of Public Service Employees: Evidence From Schools. Public Personnel Management, 45(4), 360-381. https: / /doi.org/10.1177/0091026016675374

Radarcirebon.com. (2020, April 4). Penduduk Miskin Turun, Tapi Keparahan Kemiskinan Naik. https://www.radarcirebon.com/2020/04/04/penduduk-miskin-turun-tapi-keparahankemiskinan-naik/

Rakhman, R. H. (2019). Accountability of Village Fund Management by Village Government in Indrasari Village, Martapura District, Indonesia. European Journal of Political Science Studies. http://dx.doi.org/10.46827/ejpss.v0i0.616

Randa, F., \& Tangke, P. (2015). Developing accountability model of local government organization: from managerial accountability to public accountability (naturalistic study on local government Tana Toraja). Procedia-Social and Behavioral Sciences, 211, 665-672. https://doi.org/10.1016/j.sbspro.2015.11.099 
Republika.co.id. (2020, September 7). Angka Kemiskinan di Bogor Diprediksi Melonjak. https://republika.co.id/berita/qgamgl480/angka-kemiskinan-di-bogor-diprediksimelonjak

Romzek, B. S., \& Dubnick, M. J. (1987). Accountability in the public sector: Lessons from the Challenger tragedy. Public Administration Review, 47(3), 227-238. https://doi.org/10.2307/975901

Savitri, E., Andreas, A., \& Diyanto, V. (2019). Accountability Of Village Funds Management. Jurnal Aplikasi Manajemen, 17(3), 515-521. http://dx.doi.org/10.21776/ub.jam.2019.017.03.16

Schweiker, W. (1993). Accounting for Ourselves: Accounting Practice and the Discourse of Ethics. Accounting, Organizations and Society, 18(2-3), 231-252. https://doi.org/10.1016/0361-3682(93)90035-5

Siwalimanews.com. (2020, June 9). Diduga, Penyaluran BLT Desa Oki Lama Bermasalah. https://siwalimanews.com/diduga-penyaluran-blt-desa-oki-lama-bermasalah/

Smith, A. E. (2014). On the Edge of a Glass Cliff: Women in Leadership in Local Government. Academy of Management Proceedings, 2014(1), 15946-15946. https://doi.org/10.5465/ambpp.2014.15946abstract

Sonowal, M. D. (2013). Impact of Education in Women Empowerment: A Case Study of SC and ST women of Sonitpur District, Assam. International Journal of Computer Applications in Engineering Sciences, Suppl., Special, 27-33.

http://citeseerx.ist.psu.edu/viewdoc/download?doi=10.1.1.303.2672\&rep=rep1\&type= pdf

Williamson, S., Carson, L., \& Foley, M. (2019). Representations of New Public Management in Australian Public Service gender equality policies. Equality, Diversity and Inclusion: An International Journal. https://doi.org/10.1108/EDI-05-2019-0145

Yunita, A., \& Christianingrum, M. (2018). Measurement of Accountability Management of Village Funds. Integrated Journal of Business and Economics, 2(1), 99-103. 